\title{
Influence of Anodic Gas Mixture Composition on Solid Oxide Fuel Cell Performance: Part 1
}

\author{
N. Murgi, G. De Lorenzo, O. Corigliano, F. A. Mirandola and P. Fragiacomo * \\ Department of Mechanical, Energy and Management Engineering - University of Calabria
}

Arcavacata di Rende, 87036 Cosenza, Italy

Email: petronilla.fragiacomo@unical.it

\begin{abstract}
Solid oxide fuel cells can be fed not only by conventional fuels (methane or hydrogen), but also by nonconventional fuels such as syngas $\left(\mathrm{H}_{2}, \mathrm{CO}, \mathrm{N}_{2}, \mathrm{CO}_{2}, \mathrm{H}_{2} \mathrm{O}\right)$.

In terms of $\mathrm{CO} / \mathrm{H}_{2}$ ratio, $\mathrm{N}_{2}, \mathrm{CO}_{2}$ and $\mathrm{H}_{2} \mathrm{O}$ concentrations, and mass flow, the anodic gas mixture composition can affect SOFC performance and create a carbon deposition phenomenon.

In this paper a careful analysis of SOFCs performance for varying concentrations of the gas components of a generic stream of syngas and operating conditions (pressure, temperature), was performed in order to plan the actual test campaigns.

This study showed that the $\mathrm{CO} / \mathrm{H}_{2}$ ratio is the parameter to which must be given the most attention. This factor not only directly affects the performance of the fuel cell, but also affects its useful life, because carbon deposition is directly determined by the concentration of $\mathrm{CO}$ in the gas-mixture. The ratio has been found that provides the best performance without incurring in carbon deposition, which is in the range $20 / 80 \div 35 / 65$.

The paper reports a first stage of analysis (Part 1), whereas the second stage of analysis is reported in a subsequent paper (Part 2) where performances are assessed with regards to main operating parameters.
\end{abstract}

Keywords: SOFC, Syngas, Hydrogen, Clean energy.

\section{INTRODUCTION}

Current issues such as the gradual exhaustion of fossil fuel reserves and the simultaneous increase in global energy demand, high oil prices, pollution and climate change of the planet have now been for several years at the center of national and international debates [1].

In this regard, on 17 December 2007 the European Parliament, as part of the strategy 20/20/20 European Union (EU), approved the climate-energy package, designed to achieving the objectives that the EU has set for 2020: $20 \%$ reduction in EU greenhouse gas (GHG) emissions from 1990 levels; raising the share of EU energy consumption produced from renewable resources to $20 \%$ and a $20 \%$ improvement in the EU's energy efficiency [2].

One of the strategies that may prove suitable for the energy needs of the EU, consists in the differentiation of sources and in the diversification and improvement of the systems of energy production.

In this context, the technology based on the use of solid oxide fuel cell has many advantages in terms of energy efficiency and environmental impact [3,4].

These can be fed not only with $\mathrm{H}_{2}$ but also with natural gas, gas from fossil fuels or biomass, unlike the fuel cell at low temperatures which only require the use of pure fuels.
In this paper, the significant aspects that characterize the solid oxide fuel cell (SOFC) will be presented and discussed, considering the particular syngas feed.

The aim of this work is to analyze the performances of the SOFCs, at varying concentrations of gas components of a generic stream of syngas $\left(\mathrm{H}_{2}, \mathrm{CO}, \mathrm{N}_{2}, \mathrm{CO}_{2}, \mathrm{H}_{2} \mathrm{O}\right)$ and operating conditions (pressure, temperature, flow rate of the mixture), in order to plan wide test campaigns to be performed on an SOFC laboratory prototype and so understand the correct and secure functioning of the device. The use of syngas as supply stream to an SOFC is of considerable interest, both in terms of performance and environmental impact, particularly when deriving from the gasification of a biomass. However, there are some critical problems yet to be solved that undermine the stability of the fuel cell operation, such as:

- the strong dependence of the fuel cell performance on the composition of the syngas, which varies according to the type of biomass or coal and the process used $[5,6]$;

- the carbon formation, which depositing on the anode surfaces, affects fuel cell performance [7].

This first paper (Part 1) reports a first stage of analysis mainly focused on evaluating the influence of gas composition, on SOFC performances and on secure functioning free from carbon. The second stage of analysis is 
then reported in the second paper (Part 2), where performances are assessed with regards to main operating parameters.

The effects the significant parameters have on the fuel cell performance will then be exhibited, by the analysis of which testing campaigns will be planned to perform for a laboratory prototype.

\section{INFLUENCE OF COMPOSITION ON PERFORMANCE}

We are going to evaluate, therefore, the effect that the ratio $\mathrm{H}_{2} / \mathrm{CO}$; concentrations of $\mathrm{N}_{2}, \mathrm{CO}_{2}$ and $\mathrm{H}_{2} \mathrm{O}$; the temperature and the pressure; have on the fuel cell performance and on the phenomenon of carbon deposition. In conclusion, the maximum planning of tests to be performed on laboratory experimental Fuel Cell will be deduced.

\subsection{Effect of $\mathrm{CO} / \mathrm{H}_{2}$ ratio}

An understanding of how SOFCs utilize and tolerate $\mathrm{CO}$, different ratios of $\mathrm{CO} / \mathrm{H}_{2}$ are analyzed.

With a mixture of $\mathrm{H}_{2}$ and $\mathrm{CO}$ as fuel, each has a corresponding electrochemical oxidation reaction at the anode:

$$
\begin{aligned}
& \mathrm{H}_{2}+\mathrm{O}^{2-} \rightarrow \mathrm{H}_{2} \mathrm{O}+2 e^{-} \\
& \mathrm{CO}+\mathrm{O}^{2-} \rightarrow \mathrm{CO}_{2}+2 e^{-}
\end{aligned}
$$

The direct oxidation of $\mathrm{CO}$ is slower than $\mathrm{H}_{2}$ oxidation [9] and becomes particularly important for high current densities [10].

Furthermore, when steam $\left(\mathrm{H}_{2} \mathrm{O}\right)$ is present in the fuel feed, the water shift reaction (WGS) must also be considered:

$$
\mathrm{CO}+\mathrm{H}_{2} \mathrm{O} \leftrightarrow \mathrm{CO}_{2}+\mathrm{H}_{2}
$$

This equation shows that when appreciable concentrations of steam are present in the fuel feed, e.g. particularly at high fuel utilization, the $\mathrm{CO}$ concentration will be lowered in favor of $\mathrm{H}_{2}$ production.

The kinetics of this reaction are fast and favorable, much more so when compared to the direct oxidation of CO [9], therefore the presence of steam will cause the reaction to proceed, generating $\mathrm{H}_{2}$.

However, according to Andreassi et al. [8], the sole consideration of WGS reaction (not CO oxidation) implies an underestimation of the voltage, as demonstrated experimentally.

Traditionally, the most common anode material for SOFCs with a YSZ electrolyte layer is an Ni-YSZ cermet. Although $\mathrm{Ni}$ has a high activity for $\mathrm{H}_{2}$ electrochemical oxidation, it is not an effective catalyst for $\mathrm{CO}$ oxidation. In addition, since $\mathrm{H}_{2}$ has a lower surface diffusion resistance on $\mathrm{Ni}$ when compared to $\mathrm{CO}$, the amount of $\mathrm{H}_{2}$ which can be oxidized is expected to be higher. This contributes to a reaction rate constant which is $2-3$ times higher at temperatures between 750 and $1000{ }^{\circ} \mathrm{C}$ for $\mathrm{H}_{2}$ compared to $\mathrm{CO}$ on $\mathrm{Ni}-\mathrm{YSZ}$ cermet anodes $[9,10]$. Some reported performances with Ni-YSZbased cermet anodes have shown that the performance with a $\mathrm{CO} / \mathrm{H}_{2}$ mixed fuel, as measured by exchange current densities or power densities, produces intermediate values when compared to pure $\mathrm{H}_{2}$ or $\mathrm{CO}$ fuel $[9,10]$.

However, the trend between the higher pure $\mathrm{H}_{2}$ value and the lower $\mathrm{CO}$ values is monotonic but not linear.

\section{Case study a)}

A first analysis (case study a) is carried out on the basis of a thorough study, both experimentally and by numerical modeling, performed by Suwanwarangkul et Al. [11] on an SOFC (anode: $\mathrm{Ni}-\mathrm{CeO}_{2}$-YSZ) operating with syngas at a temperature of $800{ }^{\circ} \mathrm{C}$ and $900{ }^{\circ} \mathrm{C}$.

The mentioned article shows the experimental and predicted fuel cell performances for $\mathrm{H}_{2} / \mathrm{CO}$ ratios diluted with $70 \% \mathrm{~N}_{2}$ to reduce the rate of carbon formation that is determined by the $\mathrm{CO}$ concentration in the fuel gas.

The model only slightly underestimates the measured performance data at both temperatures. The OCV is essentially independent of the relative proportions of $\mathrm{H}_{2}$ and $\mathrm{CO}$. Moreover, the fuel cell performance achieved when $\mathrm{CO}$ is the only oxidizable gas is slightly lower than that obtained when $\mathrm{H}_{2}$ is the only fuel.

This means that, in case of dilution of $\mathrm{N}_{2}$, even though the $\mathrm{CO}$ oxidation rate is less than the $\mathrm{H}_{2}$ oxidation rate, it has only a small effect on the relative fuel cell performance. The main reason for this is that the cathodic overpotential plays a larger role on the fuel cell performance than the anodic overpotential $[12,13]$.

\section{Case study b)}

We will use, in this case, the experimental analysis, performed by Julie S. O'Brien and Javier B. Giorgi, of a SOFC (anode: $\mathrm{Ni}_{0.7} \mathrm{Co}_{0.3}$-YSZ) operating at $800{ }^{\circ} \mathrm{C}$ with a variable $\mathrm{CO} / \mathrm{H}_{2}$ ratio in the entire concentration range (case study b)

Experiments conducted in this work were performed on two identical fuel cells varying the $\mathrm{CO} / \mathrm{H}_{2}$ ratio, following an increasing trend for "cell 1 " and decreasing for "cell 2 ".

For the fuel cell designated as "cell 1", data for pure $\mathrm{H}_{2}$ was collected followed by increasing amounts of $\mathrm{CO}$ until pure $\mathrm{CO}$ was reached, at which point a measurement at 50/50 $\mathrm{CO} / \mathrm{H}_{2}$ was collected, followed by a return to pure $\mathrm{H}_{2}$.

For "cell 2", data for pure $\mathrm{H}_{2}$ was initially collected for comparison purposes with "cell 1", then the fuel was switched rapidly to pure $\mathrm{CO}$ and the concentration of $\mathrm{CO}$ was systematically lowered until pure $\mathrm{H}_{2}$ was collected. A further checkpoint at $50 / 50 \mathrm{CO} / \mathrm{H}_{2}$ was then collected followed by a return to pure $\mathrm{H}_{2}$.

This work showed an excellent agreement between fuel cells 1 and 2 especially when the $\mathrm{CO}$ percentage was between 20 and $80 \%$; the same plateau was observed with a similar constant value, indicating the independence of the order of data collection in relation to the chemical mechanism occurring.

However, upon returning to a 50/50 mixture, a large drop in the OCV value was observed $(\sim 0.8 \mathrm{~V})$ indicating an inability of both fuel cells to tolerate fuel mixture cycling and the accumulation of carbon over time. This is also confirmed by the lowered final OCV point at $0.68 \mathrm{~V}$ in pure $\mathrm{H}_{2}$.

Moreover, for fuel feed ratios $\left(\mathrm{CO} / \mathrm{H}_{2}\right)$ of $20 / 80$ and $30 / 70$, the exchange current density $\left(\mathrm{i}_{0}\right)$ values increased by a factor of 5.7 and 7.3 times respectively compared to power with pure hydrogen.

This is a very encouraging result, as $i_{0}$ increases the activation polarization reduces its value, subsequently 
implying an increase in the fuel cell voltage that contrasts in some way with the voltage reduction compared to the optimal case of operation with pure $\mathrm{H}_{2}$.

These findings are also important since this is the first example of an Ni-Co-based cermet anode producing exchange current densities which are larger for $\mathrm{CO} / \mathrm{H}_{2}$ fuel mixtures when compared to pure $\mathrm{H}_{2}$. Cell 2 values for exchange current density in the $20 / 80$ and $30 / 70 \mathrm{CO} / \mathrm{H}_{2}$ regions (after exposure to pure $\mathrm{CO}$ and increasing $\mathrm{H}_{2}$ content) are comparable to those of the pure hydrogen collected initially. These values were not higher than that for initial pure hydrogen, likely being due to cumulative carbon poisoning during measurements at higher $\mathrm{CO}$ concentration.

The fuel ratio $\left(\mathrm{CO} / \mathrm{H}_{2}\right)$ between $60 / 40$ and $80 / 20$ is clearly a composition which results in carbon poisoning, as highlighted by the behavior of both fuel cells. This confirms that the low exchange current density values shown in the region between 60 and $80 \%$ are due to this fuel composition producing a carbon poisoning effect, not because of cumulative carbon deposition, as might be proposed for the second fuel cell.

The second fuel cell showed an exchange current density in $\mathrm{CO}$ which is comparable to that of the initial hydrogen fuel. Although a modest improvement was observed in the region of $20 / 80$ and $30 / 70 \mathrm{CO} / \mathrm{H}_{2}$, the exchange current density of this fuel cell never exceeded that of the original pure hydrogen. The carbon poisoning in the higher $\mathrm{CO}$ concentration region is the likely reason for this observation.

Similar to the first fuel cell, returning to a composition of $50 / 50 \mathrm{CO} / \mathrm{H}_{2}$ and pure hydrogen showed no exchange current density $\left(\mathrm{i}_{0}=0\right)$. Carbon poisoning was also observed by a post-mortem visual examination, which showed a complete delamination of the porous anode cermet material.

As can easily be expected, it is evident that the fuel cell performance is reduced abruptly by increasing the amount of CO compared to the optimum condition at a percentage of 20 $\%$, unlike the previous case in which there is an $\mathrm{N}_{2}$ dilution of $70 \%$.

\section{Test in a time interval of 8 days with $\mathrm{CO} / \mathrm{H}_{2}$ of $25 / 75$}

To test long-term performance, a button cell was run for 7 days with the promising fuel mixture of $25 / 75 \mathrm{CO} / \mathrm{H}_{2}$ following initial measurements with pure $\mathrm{H}_{2}$.

A large $\mathrm{OCV}$ value, $1.25 \mathrm{~V}$, was obtained for pure $\mathrm{H}_{2}$, as expected (day 0). By changing the fuel composition at a $\mathrm{CO} / \mathrm{H}_{2}$ ratio of $25 / 75$, the $\mathrm{OCV}$ value dropped to a stable value of approximately $1.12 \mathrm{~V}$ for 5-7 days. In agreement with the trends observed for cells 1 and 2 , the transition to a mixture of fuel with $\mathrm{CO} / \mathrm{H}_{2}$ of $25 / 75$ produces an increase in the value of $i_{o}$ by 5 times compared to that obtained with pure $\mathrm{H}_{2}$, although this improvement decays with time.

However, despite this initial increase, from the fifth day onwards the values of the exchange current density fell below the value found for the pure hydrogen, reaching approximately zero after 7 days of testing at the ratio 25/75.

Despite this performance drop, the initial increase of $i_{o}$, with the addition of $\mathrm{CO}$, drives further research to prolong the performance gains highlighted, as this would produce important advances for the SOFC.

No visible organized carbon structures were observed following the post-run microscopy of the anode exposed for 7 days under $25 / 75$ of $\mathrm{CO} / \mathrm{H}_{2}$ fuel conditions. This confirms what was said previously on the feed ratio of $25 / 75$, which ensures less carbon deposition.
In this condition visible structures are not prevalent in this regime, therefore a different mechanism must cause the eventual degradation of the fuel cell. It is hypothesized that preferential reactivity of different sites $(\mathrm{Ni}$ and $\mathrm{Co}$ ) can give rise to a change in the anode microstructure over time under operating conditions.

A corrosion microprocess such as metal dusting is a possible explanation for the combination of the effects observed, which are: lack of carbon visible in post-mortem SEM images; corrosion of the anode material; drop of the $i_{o}$.

\section{DILUTION EFFECT OF $\mathrm{N}_{2}$ AND $\mathrm{CO}_{2}$}

To assess this effect we will take into account the work carried out in the case of study a.

The experimental results show that the fuel cell voltage increases with increasing concentration of $\mathrm{H}_{2}$, although the OCV is similar.

One of the reasons for this effect is that of course $\mathrm{N}_{2}$ and $\mathrm{CO}_{2}$ act as inert gas to the diffusion of $\mathrm{H}_{2}$ from the bulk towards the TPB (interface between electrode and electrolyte), consequently the $\mathrm{H}_{2}$ is less uniformly distributed in the electrode. Furthermore, from a thermodynamic point of view, a lower partial pressure of $\mathrm{H}_{2}$ leads to a lower fuel cell voltage.

The dilution effect of the $\mathrm{CO}_{2}$ is more pronounced than that of $\mathrm{N}_{2}$

The fuel cell performance with a mixture of $\mathrm{H}_{2}$ and $\mathrm{CO}_{2}$ are in fact lower than those with $\mathrm{H}_{2}$ and $\mathrm{N}_{2}$, for the same concentration of the fuel, this is evidenced by the significant reduction of $\mathrm{OCV}$ with increasing concentration of $\mathrm{CO}_{2}$. In essence, the $\mathrm{OCV}$ value at 800 and $900^{\circ} \mathrm{C}$ decreases by respectively $20 \%$ and $26 \%$, going from an $\mathrm{H}_{2}$ concentration of $100 \%$ to $20 \%$.

This is probably due to the effect of the reverse water gas shift (rWGS) reaction. To the mixture of $\mathrm{CO}_{2}$ and $\mathrm{H}_{2}$, the rWGS strongly influences the equilibrium compositions in converting part of the $\mathrm{H}_{2}$ and $\mathrm{CO}_{2}$ in $\mathrm{H}_{2} \mathrm{O}$ and $\mathrm{CO}$, thus causing a reduction in the concentration of $\mathrm{H}_{2}$ that is immediately reflected on the performance, generating a lower OCV.

\section{THERMODYNAMIC ANALYSIS TO VERIFY THE FORMATION OF CARBON ON THE ANODE SURFACES}

Carbon accumulation is a critical problem to be prevented since in the course of time this can lead to blockage of the active sites of the anode and eventually of the reforming catalyst, leading to the loss of fuel cell performance and poor durability [14]. In extreme cases, the accumulation of carbon can reduce the flow of gases fed causing actual physical blocks. Moreover, it can result in the growth of carbon filaments that generate massive forces within the electrode structure which can cause rapid catalyst breakdown $[11,15]$.

Poisoning by carbon is a big problem when operating with an Ni-based anode and carbon-containing fuel because of the propensity of $\mathrm{Ni}$ to cause coke formation. When, just like in syngas, a certain amount of $\mathrm{CO}$ is present, in principle, the carbon monoxide should be electrocatalytically converted into $\mathrm{CO}_{2}$, but this reaction, using the classic Ni-YSZ anode, is slow. As evidenced by today's literature, it can be assumed 
that for syngas-fed SOFCs, most carbon formation likely occurs through the Boudouard reaction, since Ni is a good catalyst for this reaction:

$2 \mathrm{CO} \rightarrow \mathrm{C}+\mathrm{CO}_{2}$

Therefore, it is important to understand the kinetics of carbon formation and determine the conditions to suppress it.

The reaction mechanism and kinetic expression for the Boudouard reaction on Ni-supported YSZ have not been well established. However, it is believed that this reaction is fast enough to attain equilibrium [11].

Therefore, a thermodynamic analysis of carbon formation rather than a kinetic analysis was considered to determine suitable operating conditions such as feed composition, temperature and pressure to suppress carbon deposition.

Based on the thermodynamics of the Boudouard reaction, carbon can form when:

$\alpha_{\mathrm{B}}=\mathrm{K}_{\mathrm{eq}, \mathrm{B}} \mathrm{p}_{\mathrm{CO}}^{2} / \mathrm{p}_{\mathrm{CO}_{2}}>1$

where $\mathrm{K}_{\mathrm{eq}, \mathrm{B}}$ is the equilibrium constant of the Boudouard reaction, which decreases as the operating temperature rises, $\mathrm{p}_{\mathrm{CO}}$ and $\mathrm{p}_{\mathrm{CO} 2}$ are the partial pressures of $\mathrm{CO}$ and $\mathrm{CO}_{2}$ respectively.

The ratio $\alpha_{\mathrm{B}}$, is sometimes referred to, more or less correctly, as "carbon activity". The possibility of carbon formation can be obtained determining values of $\mathrm{p}_{\mathrm{CO}}$ and $\mathrm{p}_{\mathrm{CO} 2}$ at various positions along the anode. The value of $\alpha_{\mathrm{B}}$ at each position is then assessed according to the criterion given in Eq. (5) to determine whether carbon formation is thermodynamically possible [11].

Therefore, the effect of the CO content and current density on the carbon activity for operation at 800 and $900{ }^{\circ} \mathrm{C}$ is studied.

A first stage of analysis carried out on the bases of the assessments reported in [11] indicates that the CO content and current density have a significant effect on the possibility of carbon formation (i.e., $\alpha_{\mathrm{B}}>1$ ) for fuel cell operation at $800^{\circ} \mathrm{C}$. In contrast, carbon formation can be avoided at $900^{\circ} \mathrm{C}$ over the entire range of current density and $\mathrm{CO}$ contents because of the lower equilibrium constant for the Boudouard reaction at the higher temperature.

Nonetheless, operation at $800^{\circ} \mathrm{C}$ or below is potentially more attractive because of the wider choice of materials that can be used for fuel cell components. It is also observed that the likelihood of carbon formation at $800^{\circ} \mathrm{C}$ can be reduced by operating at higher current density and lower $\mathrm{CO}$ content.

An increase in current density enhances the rate of $\mathrm{H}_{2}$ and $\mathrm{CO}$ oxidation and the rate of $\mathrm{H}_{2} \mathrm{O}$ and $\mathrm{CO}_{2}$ production. Thereafter, $\mathrm{H}_{2} \mathrm{O}$ reacts with $\mathrm{CO}$ via the WGS to form more $\mathrm{CO}_{2}$ and $\mathrm{H}_{2}$. These effects tend to reduce at lower $\alpha_{\mathrm{B}}$. As for pressure influence, an increase in operating pressure favors carbon formation, especially at high $\mathrm{CO}$ content and low current density. The operation at 3 bar is a border line for carbon formation. Clearly, safe functioning is also determined by other factors such as $\mathrm{CO}$ content and required electric current.

Focusing on a laboratory testing point of view, temperature conditions that are around the $750{ }^{\circ} \mathrm{C}$ are those to reach and properly study in advance. By fueling with exclusively dry fuel such as a mixture of $\mathrm{H}_{2}$ and $\mathrm{CO}$, theoretical studies in the scientific literature demonstrate that at a temperature of $800^{\circ} \mathrm{C}$ and $3 \mathrm{bar}$, although supposed high, unreliable and low fuel cell performance due to carbon formation occurs.

One of the possible ways to reduce this likelihood is to add to the fuel amounts of $\mathrm{H}_{2} \mathrm{O}$ and $\mathrm{CO}_{2}$ in the inlet stream, since $\mathrm{H}_{2} \mathrm{O}$ and $\mathrm{CO}_{2}$ (especially $\mathrm{CO}_{2}$ ) are products of the phenomena that cause carbon deposition. Hence, by adding $\mathrm{CO}_{2}$ and $\mathrm{H}_{2} \mathrm{O}$, in addition to obtaining a fuel dilution (positive to prevent carbon), a natural barrier to carbon occurs since they tend to shift the reaction to reactant side. Another helpful factor promoted by the $\mathrm{H}_{2} \mathrm{O}$ is that its presence promotes the WGS reaction, thereby reducing the concentration of $\mathrm{CO}$. By acting on the current density, carbon formation can further be prevented, as electric current acts directly on the conversion of $\mathrm{H}_{2}$ and $\mathrm{CO}$ respectively into $\mathrm{H}_{2} \mathrm{O}$ and $\mathrm{CO}_{2}$.

The effects of the current density and $\mathrm{CO}$ content on $\alpha_{\mathrm{c}}$ at various inlet $\mathrm{H}_{2} \mathrm{O}$ and $\mathrm{CO}_{2}$ compositions at $800^{\circ} \mathrm{C}$ and 3 bar are then evaluated. The likelihood of carbon formation is substantially decreased by increasing $\mathrm{H}_{2} \mathrm{O}$ or $\mathrm{CO}_{2}$ concentration in the inlet stream especially at high $\mathrm{CO}$ content.

A syngas fuel containing $50-60 \% \mathrm{CO}$ content requires at least $20 \% \mathrm{H}_{2} \mathrm{O}$ or $\mathrm{CO}_{2}$ concentration to reduce the risk of carbon formation during operation. Unfortunately, fuel cell power will be slightly reduced since this tends to lower the OCV. To better understand, the authors analyzed the aforementioned observations by performing a campaign of numerical simulations based on a supply of syngas, whose model details are reported in $[16,17]$. The analyses are aimed at evaluating carbon formation through the $\alpha$ parameter, in relation to the $\mathrm{CO}$ content in the fuel, to the current density, to the operating temperature, and to the pressure. The fuel is supposed to be a syngas with variable $\mathrm{CO} / \mathrm{H}_{2}$ ratio and with the following ratio of $\mathrm{H}_{2} \mathrm{O} / \mathrm{CO}_{2} / \mathrm{N}_{2}, 10 / 10 / 10,10 / 20 / 0$, $15 / 15 / 0$, and $20 / 10 / 0$.

Moreover, the analyses evaluate carbon formation both at cell operations (Figure $1(\mathrm{a}-\mathrm{b})$ ) and at fuel cell inlet (Figure 1 (b)), as expected, increases of pressures affect the phenomenon negatively (Figure 1 (a)). At 3 bar, higher $\mathrm{CO}$ content are tolerated only for higher current densities. Figure 1 (b) shows that to operate at higher temperature (around 700 ${ }^{\circ} \mathrm{C}$ ) it is opportune to consider safe operations.

A more precise comments can be made on Figure 1 (c) presenting the NO carbon formation region. As can be observed, by operating at $700{ }^{\circ} \mathrm{C}$ (temperature widely adopted in laboratory testing) it is opportune to feed with a CO content no larger than $25 \%$ in the supply to prevent the phenomenon. The fuel mixture which presents the safest qualities among those analyzed is that with the largest amount of $\mathrm{CO}_{2}$.

\section{CONCLUSIONS}

The first stage of analysis reported in this paper (Part 1) focused mainly on evaluating the influence of gas composition, on SOFC performances and on secure functioning, free from carbon deposition.

The fuel ratio, $\mathrm{CO} / \mathrm{H}_{2}$, between $60 / 40$ and $80 / 20$ was found as a range in which carbon poisoning occurs, these observations being drawn from two case studies.

A test using a time interval of 8 days with $\mathrm{CO} / \mathrm{H}_{2}$ of $25 / 75$ was conducted for assessing long-term performance. A first $\mathrm{OCV}$ value of $1.25 \mathrm{~V}$, for pure $\mathrm{H}_{2}$, dropped immediately to a 
stable value of approximately $1.12 \mathrm{~V}$, with an increase in the value of $i_{o}$ by 5 times, by changing composition. Observation was over 5-7 days.

A dilution tests with $\mathrm{N}_{2}$ and $\mathrm{CO}_{2}$ demonstrated that $\mathrm{CO}_{2}$ affects performances more negatively, owing to possible reverse water gas shift triggering. Nevertheless, $\mathrm{CO}_{2}$ dilution enhances secure functioning, preventing carbon deposits.
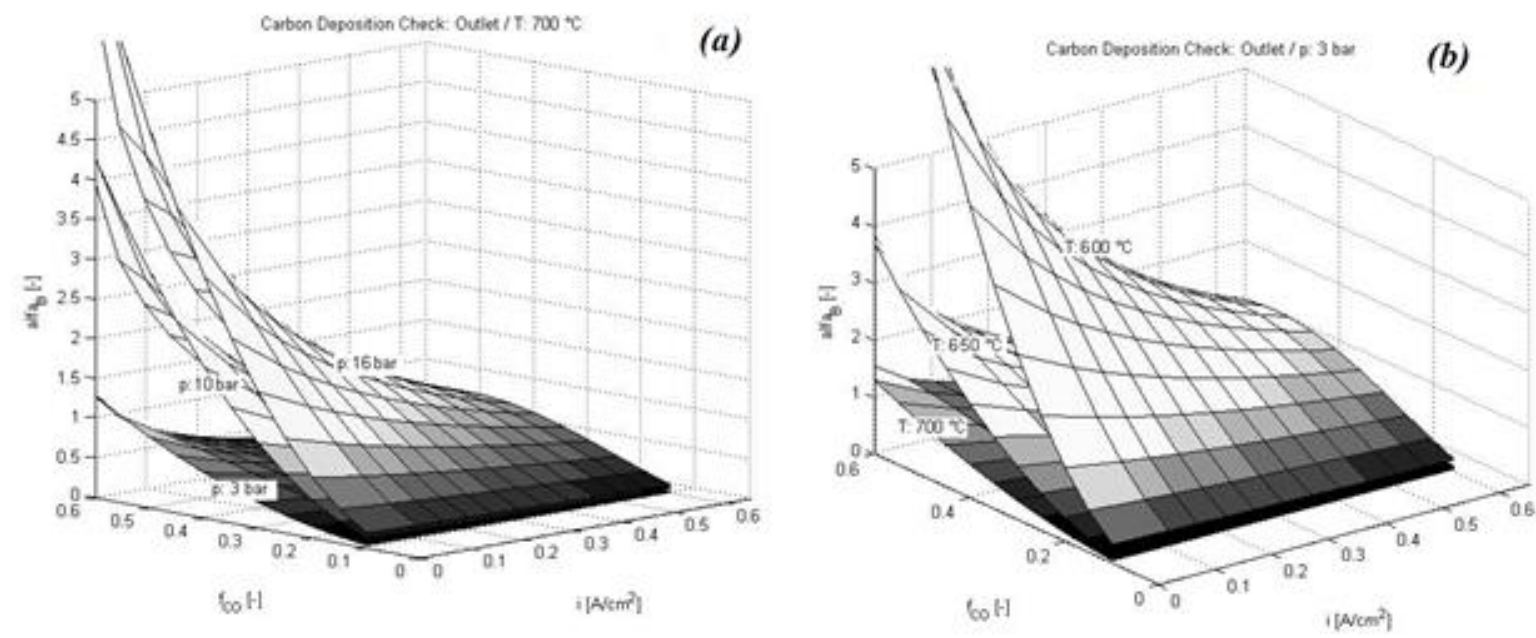

(c)

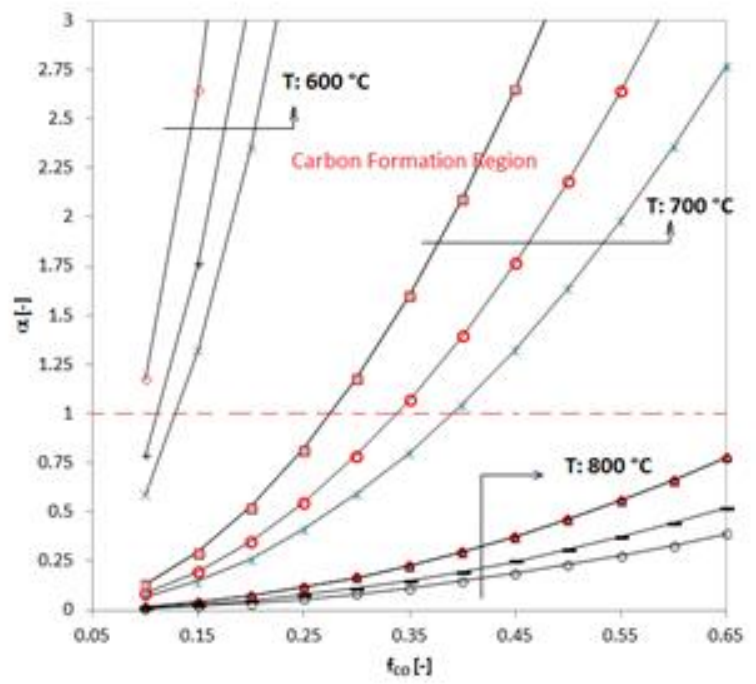

\begin{tabular}{|c|c|}
\hline $.6000 \mathrm{x}$. & Hetecos/ne: $10 / 20 / 10$ \\
\hline $0-7>700 x$ & ne0,cos/ne $10 / 20 / 10$ \\
\hline$\rightarrow r 800 x$ & 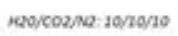 \\
\hline$\rightarrow+800 x$ & 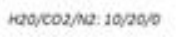 \\
\hline$\rightarrow-2 n 00 x$ & 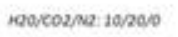 \\
\hline$\rightarrow-7.800 x$ & ne01002/Ne $10 / 2010$ \\
\hline$+r 000 x$ & 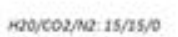 \\
\hline$-0-2000 x$ & reop/c02/Ne: : $15 / 75 / 0$ \\
\hline -7.800x & neq/cos/ng: $15 / 15 / 10$ \\
\hline$-6-800 x$ & 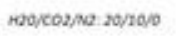 \\
\hline an & new/c02/Nu: $20 / 10 \%$ \\
\hline$\Rightarrow r 800 x$ & 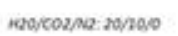 \\
\hline
\end{tabular}

Figure 1. Carbon formation assessment at fuel cell operations by feeding syngas with $\mathrm{f}_{\mathrm{CO}}$ variable, $\mathrm{H}_{2} \mathrm{O} / \mathrm{CO}_{2} / \mathrm{N}_{2}: 10 / 10 / 10$, at different temperatures / parameter pressure (a); at different pressures / parameter Temperature (b); Carbon formation assessment at fuel cell inlet by feeding syngas with $\mathrm{CO} / \mathrm{H}_{2}$ variable ratio and with the ratio of $\mathrm{H}_{2} \mathrm{O} / \mathrm{CO}_{2} / \mathrm{N}_{2}$, of 10/10/10, 10/20/0, 15/15/0, and 20/10/0, at pressure of 1 bar c)

The latter phenomenon was attributed mainly to the Boudouard reaction that favors carbon from carbon monoxide, since it is a large content of syngas. Studies and numerical analysis revealed that higher temperatures tend to prevent carbon. A safety temperature can be set to about $700^{\circ}$ C. While pressure has a negative effect and favors carbon production.

A second stage of analysis is then reported in Part 2, where performances are assessed with regard to main operating parameters.

The effects the significant parameters have on fuel cell performance, will then be exhibited by the analysis of the planned testing campaigns to be performed on a generic laboratory prototype.

\section{REFERENCES}

[1] A. Mirandola and E. Lorenzini, "Energy, environment and climate: From the past to the future," Internatiomal Journal of Heat and Technology, vol. 34 , no. 2, pp. 159-164, 2016. DOI: 10.18280/ijht.340201. 
[2] Climate-energy 2020 Package, Available: http:/ec.europa.eu/clima/policies/strategies/2020/inde $\mathrm{x}$ en.htm.

[3] I. Mejri, A. Mahmoudi, M. A. Abbassi and A. Omri "LBM simulation of heat transfer in solid oxide fuel cell," Internatiomal Journal of Heat and Technology, vol. 34, no. 3, pp. 351-356, 2016.

DOI: $10.18280 / \mathrm{ijht} .340301$.

[4] L. J. M. J. Blomen and M. N. Mugerwa, Fuel Cell Systems, New York: Plenum Press, 1993

[5] S. Onuma, A. Kaimai, K. Kawamura, Y. Nigara, T. Kawada, J. Mizusaki and H. Tagawa, "Influence of the coexisting gases on the electrochemical reaction rates between 873 and $1173 \mathrm{~K}$ in a $\mathrm{CH}_{4}-\mathrm{H}_{2} \mathrm{O} / \mathrm{Pt} / \mathrm{YSZ}$ system," Solid State Ionics, vol. 132, no. 3-4, pp. 309321, 2000. DOI: 10.1016/S0167-2738(00)00647-0.

[6] S. Baron, N. Brandon, A. Atkinson, B. Steele and R. Rudkin, "The impact of wood-derived gasification gases on Ni-CGO anodes in intermediate temperature solid oxide fuel cells," J. Power Sources, vol. 126, pp. 58-66, 2004. DOI: 10.1016/j.jpowsour.2003.09.042.

[7] J. Larminie, A. Dicks, Fuel Cell Systems Explained, Wiley, Chichester, 2003

[8] L. Andreassi, C. Toro and S. Ubertini, "Modeling carbon monoxide direct oxidation in solid oxide fuel cells," J. Fuel Cell Science and Technology, vol. 6, pp. 15, 2009. DOI: $10.1115 / 1.3080552$.

[9] Y. Matsuzaki and I. Yasuda, "Electrochemical oxidation of $\mathrm{H}_{2}$ and $\mathrm{CO}$ in a $\mathrm{H}_{2}-\mathrm{H}_{2} \mathrm{O}-\mathrm{CO}-\mathrm{CO}_{2}$ system at the interface of a Ni-YSZ cermet electrode and YSZ electrolyte," J. Electrochem. Soc., vol. 147, no 5, pp. 1630-1635, 2000. DOI: 10.1149/1.1393409.

[10] Y. Matzusaki, M. Hishinuma, I. Yasuda, S. C. Singhal and M. Dokiya, in Proc. of $6^{\text {th }}$ International Symposium on Solid Oxide Fuel Cell (SOFC VI), PV 99-19, The Electrochemical Society Proceedings Series, Pennington, NJ, 1999, pp. 560-567.

[11] R. Suwanwarangkul, E. Croiset, E. Entchev, S. Charojrochkul, M. D. Pritzker, M. W. Fowler, P. L. Douglas, S. Chewathanakup and H. Mahaudom, "Experimental and modeling study of solid oxide fuel cell operating with syngas fuel," J. Power Sources, vol. 161, pp. 308-322, 2006. DOI: 10.1016/j.jpowsour.2006.03.080.

[12] H. Koh, Y. S. Yoo, J. W. Park and H. C. Lim, "Carbon deposition and cell performance of Ni-YSZ anode support SOFC with methane fuel," Solid State Ionics, vol. 149 , pp. 157-166, 2002. DOI: 10.1016/S01672738(02)00243-6.

[13] Julie S. O'Brien and Javier B. Giorgi, "Solid oxide fuel cell with $\mathrm{NiCo}-\mathrm{YSZ}$ cermet anode for oxidation of $\mathrm{CO} / \mathrm{H}_{2}$ fuel mixtures," J. Power Sources, vol. 200, pp. $14-20,2012 . \quad$ DOI: 10.1016/j.jpowsour.2011.10.080.

[14] S. C. Singhal and K. Kendall, High-temperature Solid Oxide Fuel Cells Fundamentals, Design and Applications, Elsevier, Oxford, 2003.

[15] S. H. Clarke, A. L. Dicks, K. Pointon, T. A. Smith and T. Swann, "Catalytic aspects of the steam reforming of hydrocarbons in internal reforming fuel cells," Catalysis Today, vol. 38, pp. 411-423, 1997. DOI: 10.1016/S0920-5861(97)00052-7.

[16] O. Corigliano and P. Fragiacomo, "Technical analysis of hydrogen-rich stream generation through $\mathrm{CO}_{2}$ reforming of biogas by using numerical modeling," Fuel, 2015, vol. 158, pp. 538-548, 2015. DOI: $10.1016 /$ j.fuel.2015.05.063.

[17] G. De Lorenzo and P. Fragiacomo, "Energy analysis of an SOFC system fed by syngas," Energ. Convers. Manage. vol. 93, pp. 175-186, 2015. DOI: 10.1016/j.enconman.2014.12.086.

\section{NOMENCLATURE}

$\begin{array}{ll}\text { WGS } & \text { Water Gas Shift reaction } \\ \text { rWGS } & \text { Reverse Water Gas Shift reaction } \\ \text { OCV } & \text { Oper Circut Voltage, V } \\ \mathrm{i} & \text { Current density, A/cm }{ }^{2} \\ \text { TPB } & \text { three phase boundary } \\ \mathrm{e} & \text { electrons } \\ \mathrm{YSZ} & \text { Yttria-stabilized zirconia } \\ \mathrm{K} & \text { equilibrium constant } \\ \mathrm{p} & \text { pressure, atm } \\ \mathrm{T} & \text { temperature, }{ }^{\circ} \mathrm{C} \\ \mathrm{f} & \text { molar fraction } \\ \text { var } & \text { variable } \\ \mathrm{SEM} & \text { Scanning Electron Microscope }\end{array}$

\section{Greek symbols}

$\alpha$

Carbon deposition parameter

\section{Subscripts}

B

0

eq

$\mathrm{CO}$

Boudouard exchange current density symbol equilibrium carbon monoxide 